\title{
Is a Brain Stroke Caused by COVID-19 Seen Under Two Years of Age? A Case Report
}

\author{
COVID-19’un Neden Olduğu Beyin Felci İki Yaşın Altında Görülür mü? Olgu Sunumu
}

\author{
(1) Mohammad Vafaee Shahi ${ }^{1}$, (1) Sedigheh Yousefzadegan², (1) Ramin Zare Mahmoudabadi³, (1) Fatemeh Ahmadi ${ }^{4}$, \\ (1) Aina Riahi 5 \\ ${ }_{1}^{1}$ Pediatric Growth and Development Research Center, Iran University of Medical Sciences, Tehran, Iran \\ 2Firouzabadi Clinical Research Development Unit (FACRDU), Iran University of Medical Sciences (IUMS), Tehran, Iran \\ 3Department of Pediatrics, Firouzabadi Clinical Research Development Unit (FACRDU), Iran University of Medical Sciences, Tehran, Iran \\ ${ }^{4}$ Rasool Akram Hospital, Iran University of Medical Science, Tehran, Iran \\ 5Minimally Invasive Surgery Research Center, Iran University of Medical Science, Tehran Iran
}

\begin{abstract}
Brain ischemic stroke in children, especially in infancy, is a rare condition. Stroke presents a variety of symptoms and usually is an underestimated diagnosis in infants. The current coronavirus disease-2019 (COVID-19) pandemic involves different organs in the human body, such as the central nervous system. Researchers believe a probable association between this RNA virus and stroke but with a few cases of strokes in the pediatrics field with positive reverse transcriptionpolymerase chain reaction (RT-PCR) for severe acute respiratory syndrome coronavirus 2 (SARS CoV-2).

Herein, reported a 17-month-old girl with hemiparesis and focal status epilepticus that was admitted to Firoozabadi Hospital. The onset of symptoms was approximately 4 days before the admission with a non-bloody and watery diarrhea, nausea, vomiting, and a low-grade fever. The brain magnetic resonance imaging with diffusion-weighted imaging sequence confirmed acute ischemic stroke (AIS). COVID-19 RT-PCR test was requested due to the multisystemic involvement, which revealed a positive result. Thus, according to the positive RT-PCR and other negative results along with fever and gastrointestinal involvement, which is a common form of COVID-19 infection in pediatric patients, her neurological symptoms were confirmed with COVID-19 infection. Based on our knowledge, this is the first case of AIS due to SARS CoV-2 infection that was reported under 2 years of age worldwide.

COVID-19 infection in pediatric patients has different presentations. In a significant number of these patients, the involvement of more than two body organs could be seen, known as "multisystem inflammatory syndrome in children" that is associated with COVID-19. Some strokes due to COVID-19 infection were reported with its association to hypercoagulability state, thus we introduce a related case of one infant. According to the new emerging coronavirus and its probability of nervous system involvement, checking the COVID-19 RT-PCR test in the nasopharynx and cerebrospinal fluid of all children who present with neurological symptoms is recommended, even in the post-COVID-19 era.
\end{abstract}

Keywords: COVID-19, SARS CoV-2, infant, children, stroke, MIS-C

$\ddot{O} \mathbf{z}$

Çocuklarda özellikle bebeklik döneminde iskemik inme nadir görülen bir durumdur. İnme çeşitli semptomlarla kendini gösterir ve genellikle bebeklerde göz ardı edilen bir tanıdır. Mevcut yeni koronavirüs hastalığı-2019 (COVID-19) pandemisi, merkezi sinir sistemi gibi insan vücudundaki farklı organları tutar. Araştırmacılar, bu RNA virüsü ile felç arasında olası bir ilişki olduğuna inanıyorlar ancak pediatri alanında şiddetli akut solunum yolu sendromu koronavirüs-2'ye (SARS-CoV-2) yönelik revers-transkriptaz polimeraz zincir reaksiyonu (RT-PCR) pozitif olan sadece birkaç iskemik inmeli hasta bildirilmiştir.

Bu çalışmada Firoozabadi Hastanesine hemiparezi ve fokal status epilepticus ile başvuran 17 aylık bir kız çocuğu bildirilecektir. Hastanın kansız ve sulu ishal, bulantı, kusma ve düşük dereceli ateş semptomları başvurudan yaklaşık 4 gün önce başlamıştı. Beyin manyetik rezonans görüntüleme difüzyon ağırlıklı görüntüleme akut iskemik inmeyi doğruladı. Multisistem tutulumu nedeniyle COVID-19 RT-PCR testi istendi ve sonuç pozitif çıktı. Pozitif PCR testi sonucu ile birlikte ateş ve gastrointestinal tutulum tablosuna yol açabilecek diğer durumların dışlanması, hastadaki nörolojik semptomların COVID-19 ile açıklanabileceğini düşündürdü. Bilgilerimize göre bildirdiğimiz hasta, dünyada iki yaş altında bildirilen SARS CoV-2 enfeksiyonuna bağlı ilk akut iskemik inme olgusudur.

Address for Correspondence/Yazışma Adresi: Aina Riahi MD, Pediatric Ward, Rasool Akram Hospital, Iran University of Medical Sciences, Tehran, Iran Phone: +989121571355 - 9864352467 E-mail: ainariahi@yahoo.com - riahi.a@iums.ac.ir ORCID: orcid.org/0000-0001-8534-6892

Received/Geliş Tarihi: 11.06.2021 Accepted/Kabul Tarihi: 23.11.2021

${ }^{\circ}$ Copyright 2021 by Turkish Neurological Society

Turkish Journal of Neurology published by Galenos Publishing House. 


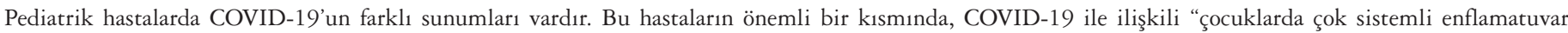

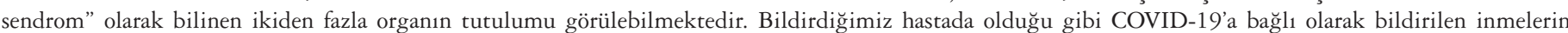

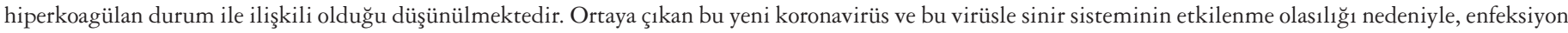

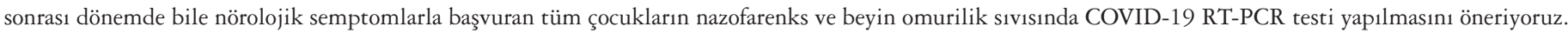

Anahtar Kelimeler: COVID-19, SARS CoV-2, bebek, çocuk, inme, MIS-C

\section{Introduction}

Brain stroke in children, especially in infancy, is a rare condition with two main types; hemorrhagic and ischemic are due to brain vessel rupture or occlusion, respectively (1). Stokes can lead to serious morbidity. Up to $25 \%$ of children will have recurrent episodes of strokes and up to $66 \%$ will have persistent neurological deficits or epilepsy $(2,3,4)$. Stroke presents with a variety of symptoms and usually is an underestimated diagnosis in infants. The etiologies of stroke are classified into 4 main categories as heart disorders, blood disorders, infections, and vascular disorders $(1,2,3,4)$. The current pandemic of coronavirus disease-2019 (COVID-19), involves different organs in the human body, such as the central nervous system. Researchers believe a probable association between this RNA virus and stroke but few reported cases of strokes in the pediatrics field with positive reverse transcription-polymerase chain reaction (RT-PCR) for severe acute respiratory syndrome coronavirus-2 (SARS-CoV-2) $(5,6,7,8)$.

Herein, reported a 17 -month-old girl with a focal neurological symptom and a positive RT-PCR test for COVID-19 infection and was admitted to Firouzabadi Hospital. The brain RT-PCR with diffusion-weighted imaging (DWI) sequence confirmed acute ischemic stroke (AIS). Based on our knowledge, this is the first case of AIS due to SARS CoV-2 infection that was reported under 2 years of age worldwide.

\section{Case Report}

A 17-month-old infant was admitted due to abnormal jerky movements of the right upper limb in favor of seizure. The onset of symptoms was approximately 4 days before the admission with non-bloody and watery diarrhea, nausea, vomiting, and low-grade fever. On the second day, she developed neurologic symptoms as frequent focal seizures that were taken $>30 \mathrm{~min}$, which worsened on the third day and she developed right-side hemiparesis of her limbs, thus the parents bring her to the emergency department. The patient was admitted while she had moderate dehydration and was ill but oriented.

Her past medical history did not show any history of illness or hospital admission. She is the fourth child of all 4 children in their family and did not have any birth complications or insult. She did not receive any special medication except acetaminophen. The family history was negative for neurological disorders. The vital signs upon admission were as follows: blood pressure of $88 / 55$ $\mathrm{mmHg}$, pulse rate of $140 / \mathrm{min}$, respiratory rate of $36 / \mathrm{min}$, the oral temperature of $37^{\circ} \mathrm{C}$, and first blood glucose of $114 \mathrm{mg} / \mathrm{dl}$. Brain nerve examinations were normal. The visual problem, neck stiffness, seizure, or jerky movement was not observed, but she had right-side deviated posture while seated and the muscle force of the right side was decreased that revealing hemiparesis. The plantar reflexes were asymmetric and upward on the right side. Deep tendon reflexes were brisk in the right limbs.

Due to her gastrointestinal symptoms, which were followed by focal seizures and right-side hemiparesis, viral encephalitis was placed on the top of the differential diagnosis list. Brain computed tomography scan without contrast showed hypodensity in the left temporoparietal region and lower corticomedullary differentiation of the left hemisphere compared with the right side (Figure 1). The brain magnetic resonance imaging with DWI sequence confirmed AIS in the left hemisphere (Figure 1). The echocardiography revealed no structural or functional abnormality. The lumbar puncture and viral panel (herpes simplex viruses, cytomegalovirus, Epstein-Barr virus, influenza, varicella, enterovirus, and human herpesvirus 6, 7, and 8) were requested. Serum ammonia, lactate, and homocysteine, and a complete panel for amino acid levels in the blood were checked for any metabolic disorder that would explain the patient's seizure and stroke. A rheumatologic panel (antinuclear antibody, dsDNA, complement components C3 and $\mathrm{C} 4$, serum hemolytic complement, antiphospholipid Ab, and anticardiolipin $\mathrm{Ab}$ ) was checked to rule out other causes of stroke. Screening investigations for inherited thrombophilia revealed normal results of protein S, C, antithrombin III, HB electrophoresis, Factor V Leiden, prothrombin time, and partial thromboplastin time (Table 1).

COVID-19 RT-PCT test was requested due to the multisystemic involvement, and the result was positive. Thus, according to the positive RT-PCR and negative other results along with fever and gastrointestinal involvement, which is a common form of COVID-19 infection in pediatric patients, her neurological symptoms could be explained with COVID-19 infection. Based on our knowledge, this is the first case of AIS due to SARS CoV-2 infection that was reported under 2 years of age worldwide. She underwent treatment with phenytoin, acyclovir, enoxaparin, and aspirin, and was discharged from the hospital in a good condition.
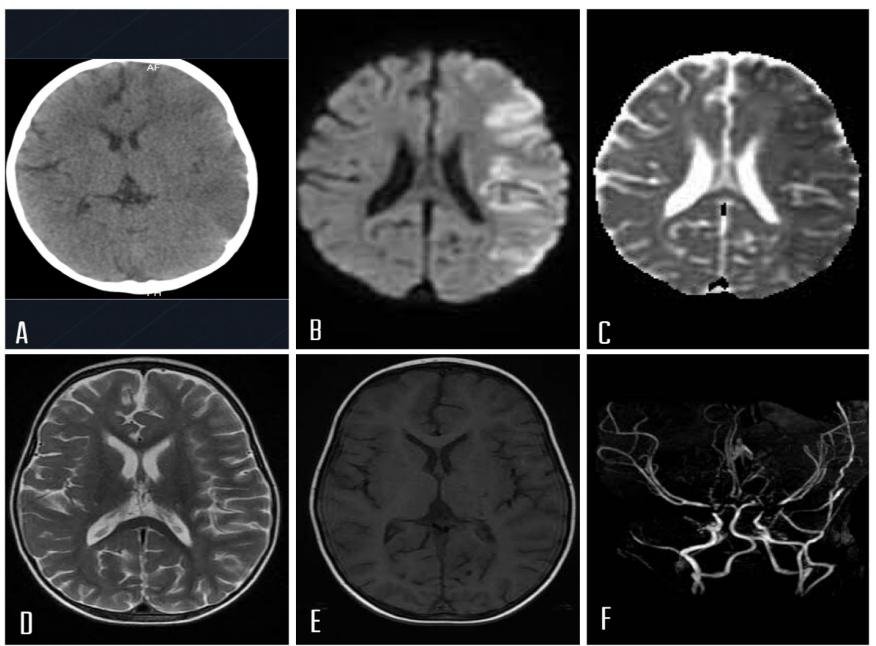

Figure 1. CT scan shows wedge-shape hypodensity in the left temporoparietal region and lower corticomedullary differentiation of the left hemisphere (A), DWI sequence of MRI reveals high-signal intensity in the left MCA territory (B), ADC map sequence of MRI reveals restriction in the involved area (C), T2 and T1 sequences of MRI show normal results (D and $\mathrm{E})$, brain MRA reveals normal result (F). 


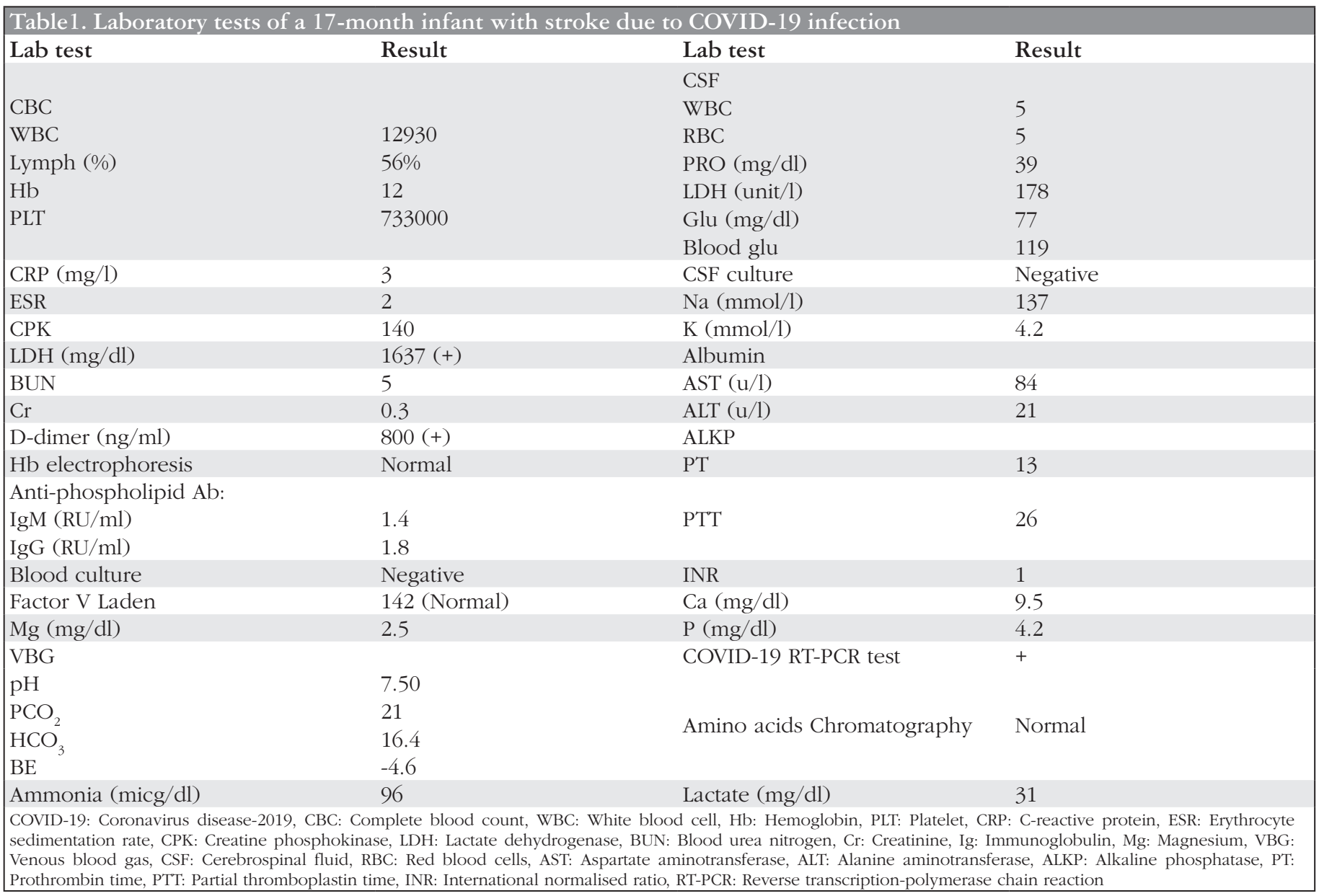

COVID-19 infection in pediatric patients has different presentations. A significant number of these patients presented with more than two body organ involvement, known as "multisystem inflammatory syndrome in children" that is associated with COVID-19. One of the involved systems could be the neurologic system, and theoretically, it could be any neurological sign with no other alternative plausible diagnoses (9). Some strokes due to COVID-19 infection were reported with an association to hypercoagulability state, thus we introduce a related case of one infant. According to this new emerging coronavirus and the probability of nervous system involvement with this virus, checking the COVID-19 RT-PCR test in the nasopharynx and cerebrospinal fluid of all children and infants who presented with neurological symptoms is recommended, even in the postCOVID-19 era.

\section{Ethics}

Informed Consent: Written informed consent was obtained from the parents of the patient for publication of this case report and any accompanying images.

Peer-review: Externally peer-reviewed.

\section{Authorship Contributions}

Surgical and Medical Practices: M.V.S., S.Y., R.Z.M., F.A., A.R., Concept: M.V.S., R.Z.M., Design: M.V.S., R.Z.M., A.R., Data Collection or Processing: S.Y., F.A., Analysis or Interpretation: M.V.S., R.Z.M., Literature Search: S.Y., F.A., A.R., Writing: S.Y., A.R.
Conflict of Interest: The authors have not declared any conflict of interest related to this article.

Financial Disclosure: No financial support was received from any institution or person for our study.

\section{References}

1. Ferriero DM, Fullerton HJ, Bernard TJ, et al. Management of Stroke in Neonates and Children: A Scientific Statement From the American Heart Association/American Stroke Association. Stroke 2019;50:e51-e96.

2. Lanthier S, Carmant L, David M, Larbrisseau A, de Veber G. Stroke in children: the coexistence of multiple risk factors predicts poor outcome. Neurology 2000;54:371-378.

3. deVeber GA, MacGregor D, Curtis R, Mayank S. Neurologic outcome in survivors of childhood arterial ischemic stroke and sinovenous thrombosis. J Child Neurol 2000;15:316-324.

4. DeVeber G. In pursuit of evidence-based treatments for paediatric stroke: the UK and Chest guidelines. Lancet Neurol 2005;4:432-436.

5. Lam K, Lee JH, Cheng P, et al. Pediatric stroke associated with a sedentary lifestyle during the SARS-CoV-2 (COVID-19) pandemic: a case report on a 17-year-old. Neurol Sci 2021;42:21-23.

6. Mirzaee SMM, Gonçalves FG, Mohammadifard M, Tavakoli SM, Vossough A. Focal Cerebral Arteriopathy in a Pediatric Patient with COVID-19. Radiology 2020;297:E274-E275.

7. Gharehbaghi G, Yousefzadegan S, Javid A, et al. COVID-19 in Children and Neonates: A Comprehensive Review Article. Iran J Pediatr 2021;31:e108095.

8. Ashrafi MR, Azizimalamiri R, Badv RS, et al. Coronavirus, Its Neurologic Manifestations, and Complications. Iran J Pediatr 2020;30:e102569.

9. CDC 24/7: saving lives, protecting people, Centers for disease control and prevention. https://www.cdc.gov/mis-c/hcp/ 